
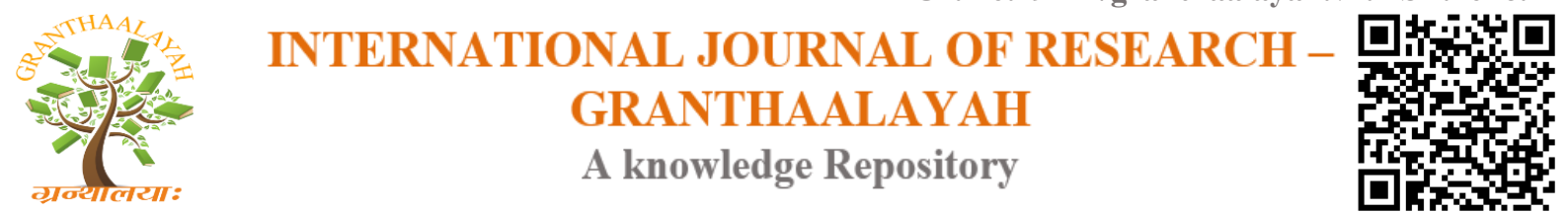

Management

\title{
A STUDY ON FINANCIAL INCLUSION OF URBAN STREET VENDORSIN PALAYAMKOTTAI
}

\author{
Dr. M. N. Mohamed Abusali Sheik ${ }^{* 1}$, M. Sareswathy ${ }^{2}$ \\ *1 Assistant Professor of Commerce, Sadakathullah Appa College, Tirunelveli, TamilNadu, \\ INDIA \\ ${ }^{2}$ M.Phil., Research Scholar, Dept of Commerce, Sadakathullah Appa College, Tirunelveli, \\ TamilNadu, INDIA
}

\begin{abstract}
Financial inclusion is an integral part of inclusive and sustainable growth process of an economy. Proper access to finance at an affordable cost to all the section of the society is a key requisite to economic growth. In a developing country like India, a large segment of the society, particularly, low income people have very little access to formal financial sector.
\end{abstract}

Keywords:

Financial inclusion, Financial exclusion, Problems associated with the financial inclusion of street vendors.

Cite This Article: Dr. M. N. Mohamed Abusali Sheik, and M. Sareswathy, "A STUDY ON FINANCIAL INCLUSION OF URBAN STREET VENDORSIN PALAYAMKOTTAI" International Journal of Research - Granthaalayah, Vol. 4, No. 4: SE (2016): 45-50.

\section{INTRODUCTION}

A street vendor means a person selling of goods or rendering invaluable services on the street at an affordable cost to the consumers at their convenient places. In modern world street vendors playing a pivotal role in satisfying the consumer's day to day requirements. Consumers are dependent on them. Earlier, men only take part in the business but nowadays women's are equal to men so they also take part in it and also facing lots of problem than men. Street vendors also act as hawkers, peddlers, etc. street vendors sell items produced by home based and small scale industries. Street vendors don't contribute only significantly to the economy, but more than half the urban population is dependent on them.

\section{FINANCIAL INCLUSION}

Financial inclusion means people should take part of growth activities and helps to increase economic growth of the country. The Government wishes that the poor people should be 
benefitted and granting loans to the needy people on regular basis through easily access by rich and poor in the country.

\section{FINANCIAL EXCLUSION}

Financial exclusion means a process or a continuum measuring the extent of difficulties an individual might encounter both in obtaining access to as well as use financial services and which result in causing them problems in leading a normal life.

\section{PROBLEMS ASSOCIATED WITH THE FINANCIAL INCLUSION OF STREET VENDORS}

From the study it is found that street vendors are far away from accessing proper banking services. They face a lot of problems while going to avail any banking services. There are many reasons which keep the street vendors away from accessing any banking service. This study found that problems are often faced by street vendors while going to access any banking service. Those are:

(a) Lack of identity proofs- Lack of identity documents, proof of address, tenure or legal rights over their place or business and evidence of their trades and professions creates inability of the street vendors to access the formal financial services. Banks hesitate to provide services on the ground that they unable to provide any legal and valid documents.

(b) Lack of financial literacy- There is a lack of financial literacy among street vendors. The street vendors are not aware about savings, credit, insurance etc. Due to lack of knowledge and awareness among street vendors about banking services available to them, they are not able to access banking services.

(c) Lack of regular substantial income - Most of the vendors in the study area have large families (number of dependents) to feed and save nothing or very less.

(d) The uncertainty of income: Frequent removal /evacuation of markets make their life more miserable because of uncertainty of income. This affects majorly to those who vend in weekly markets and removal of market for once means loss of income for the whole week. They have no security for their old age thus have to work in order to feed them till they die.

(e) low level of savings habit- Street vendors earn enough to satisfy their hunger, however, less to save anything for their future. Due to very low level of savings they stay away from opening any bank account in banks.

(f) No proper response from banks- Street vendors are informal in nature and because of this reason the banks do not pay required attention to street vendors. Because of certain reasons the banks heisted to provide services to street vendors. Lack of proper response from banks is one of the important reasons of street vendors not willing to access banking services. 
(g) Unable to provide security against credit- Banks heisted to provide micro finance to the street vendors on the ground that they unable to provide security against credit. Street vendors earn to satisfy their hunger, they do not have any valuable property to provide security against credit. Street vendors are very poor section of our society; they often fail to provide the required security against loan.

(h) Lengthy procedure of banks- Most of the vendors said that the longer number of hours they worked would in turn mean more income. It is found that in most cases, vendors work more between eight to twelve hours a day. This does not include another important aspect, namely cleaning of goods before displaying them up for sale. In the case of vegetables, this exercise is extremely important as very

Few clients would prefer to buy unwashed vegetables. Hence, the number of working hours increases because the cleaning time ranges from one to four hours a day. As they have to spend much time in vending to earn to satisfy their hunger, they stay away from accessing banking services due to lengthy procedure of banks.

\section{OBJECTIVITIES OF THE STUDY}

- To understand the concept of financial inclusion.

- To Overview the socio-economic background of the street vendors.

- To know the strategies of banks to empower the street vendors.

- To find out the ways and means of enhancing the banking services to street vendors.

- To examine the problems encountered by the street vendors while accessing banking services.

- To Offer suggestions for the effective implementation of the programme.

\section{STATEMENT OF THE PROBLEM}

Financial exclusion is often the symptom as well as the cause of poverty. Financial exclusion has been predominant in rural areas primarily due to poor infrastructure and illiteracy result in lesser access. This along with burdensome documentation and procedures, lack of customized products leads to exclusion. Thus, the poor people go to informal sources of credit for their financial needs even though it's costly. When the street vendors approach the banks they are confronted with various problems. The study makes an attempt of overwhelm all the difficulties of street vendors while availing banking services, which would turn unbankable into bankable.

\section{SCOPE OF THE STUDY}

This study is concerned with the financial inclusion of street vendors Palayamkottai. Street vendors who operate from semi-fixed stalls like folding tables, crates, etc that are removed from the streets and stored overnight. But this study aims to analyze the extent of financial inclusion of the street vendors. 


\section{METHODOLODGY OF THE STUDY}

This an empirical and exploratory study is based on both

- Primary data

- Secondary data

\section{Primary data}

Primary data were collected from 120 street vendors from Palayamkottai area.

\section{Secondary data}

Secondary data were collected from journals, maganizines, website, newspaper, book etc.,

\section{Tools and techniques}

The data collected through questionnaire has been tabulated and analyzed by using the following techniques

- Simple Percentage analysis

- Chi-square test analysis

Hypothesis

- There is no significant association between duration of work per a day and amount of earning

- There is no significant association between education and reason for selecting the business.

\section{ANALYSIS AND INTERPRETATION OF DATA}

This is a study on the Financial Inclusion of Urban street vendors in Palayamkottai. A sample if so respondents and approached by the researcher approached the respondents with a pre-tasked interview scheduled. The researcher was able to collect fully fledged information from 120 respondents, several questions were asked by the researchers to ascertain the opinions of the respondents regarding the objectives of this study opinions were collected, analyzed and are presented in the form of tables.

There is no significant association between duration of work per a day and amount of earning

Table 1: Duration of work per a day and amount of earning

\begin{tabular}{|l|l|l|l|l|}
\hline Amount of earning & \multicolumn{2}{|l|}{ Duration } & Total \\
\hline & Up to 5 hours & $5-8$ hours & Above 8 hours & \\
& & & & \\
\hline Below Rs.150 & 6 & 39 & 15 & 60 \\
\hline Above rs.150 & 5 & 27 & 28 & 60 \\
\hline Total & 11 & 66 & 43 & 120 \\
\hline
\end{tabular}

Source: Primary data

Calculated value: 6.202

Table value: 5.991 
Degree of freedom: 9

Level of significance: $5 \%$

Above table states that the calculated value (6.202) is greater than the table value (5.991).Therefore, there is an association between duration of work per a day and amount earning. Hence null hypothesis is rejected.

Table 2: There is no significant association between years of existence and holding bank account

\begin{tabular}{|l|l|l|l|}
\hline \multirow{2}{*}{ Holding bank a/c } & \multicolumn{2}{|c|}{ Years of existence } & \multirow{2}{*}{ Total } \\
\cline { 2 - 3 } & Below 10 years & Above 10 years & \\
\hline Yes & 31 & 24 & 55 \\
\hline No & 45 & 20 & 65 \\
\hline Total & 76 & 44 & 120 \\
\hline
\end{tabular}

Source: Primary data

Calculated value: 2.124

Table value: 3.841

Degree of freedom: 1

Level of significance: $5 \%$

Above table provides that the table value (3.841) is greater than the calculated value (2.124). So the null hypothesis is accepted so it is concluded that there is no relationship between years of existence and holding bank account.

\section{FINDINGS}

- Most of the street vendors are in the age group of 41-50

- All of the men and female vendors handle their problems on their own

- All of the street vendors have their business unregistered.

- Majority of the respondent have started the business on their own.

\section{SUGGESTIONS}

\section{To the street vendors}

- Lack of saving habit is the root cause of problems and hence they should be awareness among the street vendors to increase the savings and reduce expenditures particularly the time of surplus.

To the Banks

- The banks should offer all the forms in the regional language of the customers. Tamil is the regional language of Palayamkottai area customers. Hence, all the forms should be in Tamil.

- The banks should offer no frills account in order to turn unbankable to bankable 


\section{To the Government}

- The street vendors feel that the procedures are complicated in banks for loans, the procedures and formalities of the bank should be simplified and the required documents should be minimized with regional language.

- The Government should raise the financial inclusion fund and a financial inclusion technology fund, to reach banking services to the unbanked area.

\section{CONCLUSION}

The street vending in Palayamkottai is dominated by married male aged between 41 and 50 with a very less level of literacy. There are 2 major categories of business namely the sale of service product and consumer goods. Majority of the street vendors have started the business on their own owing to self-motivation and interest with their own minimum capital investment, and thus it's a form of sole selling business. Hence, they have some future plan expand their business.

\section{REFERENCES}

[1] Dr. C. Eugine Franco, and Bulomine Regi. S, "ADVANTAGES AND CHALLENGES OF E-COMMERCE CUSTOMERS AND BUSINESSES: IN INDIAN PERSPECTIVE” International Journal of Research - Granthaalayah, Vol. 4, No. 3: SE (2016): 7-13.

[2] Financial Inclusion http://en.wikipedia.org//wiki/financial inclusion

[3] Ghordue k.n(2009)"Microfinance for financial inclusion and sustainable raural development"Indian journal of marketing.vol.45,No.1,pp.47-50

[4] Golden, S. A. R. (2011). A Study On Investment Pattern And Preference Of Investors In Trichy City, Tamil Nadu. RETELL, 12(1), 20-24.

[5] http://knowledge.wharton.upenn.edu/

[6] http://wiego.org/sites/wiego.org/files/publications/files/Bhowmik_Saha_StreetVendors_In dia_UNDP-TISS.pdf

[7] http://www.american scholarspress.com/content/buseth-abstract/v4n111-art4.pdf

[8] http://www.worldwidejournals.com/

[9] Regi, S. B., \& Golden, S. A. R. (2014). Customer Preference Towards Innovative Banking Practices Available In State Bank Of India At Palayamkottai. Sankhya International Journal Of Management And Technology, 3(11 (A)), 31-33.

[10] Regi, S. B., \& Golden, S. A. R. (2014). Global Financial Crisis - Impact In India.JOURNAL OF INTERNATIONAL ACADEMIC RESEARCH FOR MULTIDISCIPLINARY, 2(1), JIARM. 